\title{
Cadherin and Catenin Alterations in Human Cancer
}

\author{
Karen M. Hajra' and Eric R. Fearon ${ }^{1-3 *}$ \\ 'Program in Cellular and Molecular Biology, University of Michigan Medical School, Ann Arbor, Michigan \\ ${ }^{2}$ Comprehensive Cancer Center, University of Michigan Medical School, Ann Arbor, Michigan \\ ${ }^{3}$ Departments of Internal Medicine, Human Genetics, and Pathology, University of Michigan Medical School, Ann Arbor, Michigan
}

\begin{abstract}
Among the hallmarks of cancer are defective cell-cell and cell-matrix adhesion. Alterations in cadherin-catenin complexes likely have a major contributing role in cell-adhesion defects in carcinomas arising in many different tissues. E-cadherin, the prototypic member of the cadherin transmembrane protein family, regulates cell adhesion by interacting with E-cadherin molecules on opposing cell surfaces. E-cadherin's function in cell adhesion is also critically dependent on its ability to interact through its cytoplasmic domain with catenin proteins. A diverse collection of defects alter cadherin-catenin function in cancer cells, including loss-of-function mutations and defects in the expression of E-cadherin and certain catenins, such as $\alpha$-catenin. Although there is much evidence that $\beta$-catenin is deregulated in cancer as a result of inactivating mutations in the APC and AXIN tumor-suppressor proteins and gain-of-function mutations in $\beta$-catenin itself, the principal consequences of $\beta$-catenin deregulation in cancer appear to be largely distinct from the effects attributable to inactivation of E-cadherin or $\alpha$-catenin. In this review, we highlight some of the specific genetic and epigenetic defects responsible for altered cadherin and catenin function in cancer, as well as potential contributions of cadherin-catenin alterations to the cancer process.
\end{abstract}

(C) 2002 Wiley-Liss, Inc.

\section{INTRODUCTION}

The cadherins were first identified as a family of single-pass transmembrane glycoproteins mediating calcium-dependent cell-cell adhesion, and it is now well recognized that they play essential roles in development, cell polarity, and tissue morphology (Takeichi, 1991). E-cadherin is arguably the prototypic member of the classical cadherin family, and it plays a critical role in epithelial cell-cell adhesion. Like the other members of the type I classical cadherin family, E-cadherin has an extracellular domain consisting of five cadherin-type repeats that interact in a calcium-dependent fashion with cadherin molecules on neighboring cells, forming essentially a "molecular zipper" (Nagar et al., 1996). E-cadherin's cytoplasmic domain is linked to the actin cytoskeleton through critical interactions with catenins. The cadherin-catenin complex is characteristically present in the adherens junction between adjacent cells in normal epithelium (Fig. 1). Disruption of the cadherin-catenin complex has been demonstrated in carcinomas arising in many tissues and has been correlated with various pathologic and clinical features, such as tumor dedifferentiation, infiltrative growth, lymph node metastasis, and a poorer patient prognosis. The long-standing observation that tumor cells demonstrate decreased cellular adhesion, as well as the observation that E-cadherin expression is frequently lost in human cancers, led investigators to hypothesize that changes in the cadherin- catenin complex may play a causative role in cancer development and progression. A considerable body of data now firmly supports this view. This review focuses on the different mechanisms by which cadherins and catenins are altered in human cancer and the distinctive functional consequences of the alterations observed.

\section{CADHERIN ALTERATIONS IN CANCER}

\section{Germline CDHI Mutations}

Perhaps the strongest evidence in support of a causal role for cadherin alterations in cancer pathogenesis is the observation that germline mutations in the gene encoding E-cadherin (Table 1) (known as $C D H 1)$ strongly predispose affected individuals to diffuse-type gastric cancer (Gayther et al., 1998; Guilford et al., 1998, 1999; Keller et al., 1999; Richards et al., 1999). In some kindreds segregating a germline $C D H 1$ mutation, individuals have

\footnotetext{
Abbreviations: APC, adenomatous polyposis coli; EGF, epidermal growth factor; GSK $3 \beta$, glycogen synthase kinase $3 \beta$; Lef, lymphoid enhancer factor; MMP, matrix metalloproteinase; Tcf, T-cell factor; RTK, receptor tyrosine kinase.

*Correspondence to: Eric R. Fearon, Division of Medical Genetics, University of Michigan Medical Center, 4301 MSRB3, $1150 \mathrm{~W}$. Medical Center Drive, Ann Arbor, MI 48109-0638.

E-mail: fearon@umich.edu

Received 24 October 2001; Accepted 17 December 2001

DOI 10.1002/gcc.10083
} 


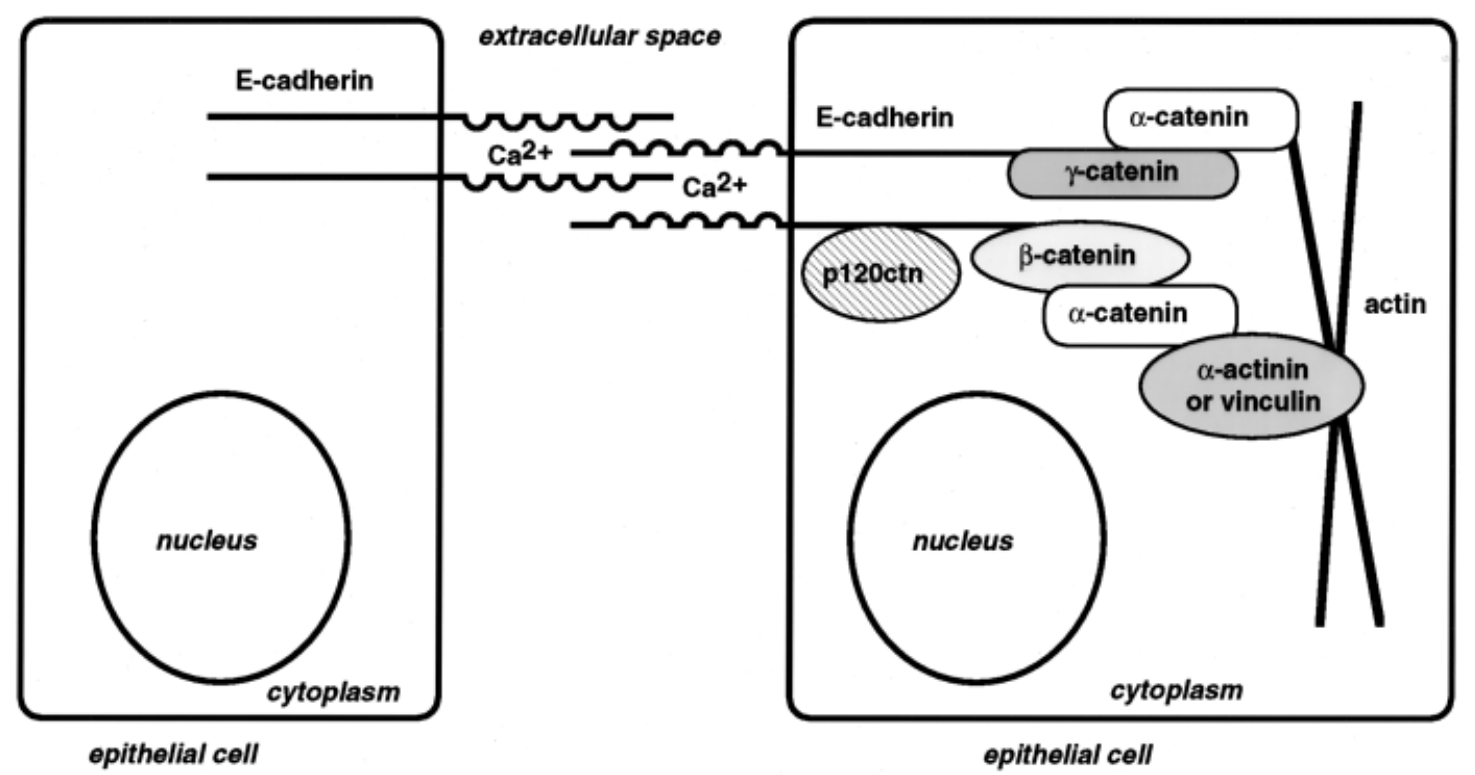

Figure I. The cadherin-catenin cell adhesion complex. E-cadherin forms intercellular, calcium-dependent, homotypic interactions. The cytoplasmic tail of E-cadherin interacts in a mutually exclusive manner with either $\beta$-catenin or $\gamma$-catenin (also called plakoglobin). $\beta$ - and $\gamma$-catenin link E-cadherin to $\alpha$-catenin, and $\alpha$-catenin can bind to the

actin cytoskeleton either directly or indirectly through a number of actin-associated proteins, including $\alpha$-actinin and vinculin. Additional proteins, such as pl20ctn (also called $\delta$-catenin), bind to the more membrane-proximal portion of the E-cadherin cytoplasmic domain.

been identified with colorectal (Guilford et al., 1998; Richards et al., 1999), breast (Guilford et al., 1999; Keller et al., 1999), and prostate (Gayther et al., 1998) cancers. However, the elevated risk of these carcinomas in individuals who carry germline CDH1 mutations is less certain than the markedly elevated risk of gastric cancer. A causal role for E-cadherin inactivation in cancer has been supported further by data showing that, in a mouse model of pancreatic $\beta$-cell cancer development, E-cadherin inactivation is a rate-limiting step in the progression from adenoma to carcinoma (Li et al., 1998).

\section{Somatic CDHI Mutations}

Somatic CDH1 gene mutations resulting in Ecadherin inactivation have also been demonstrated in carcinomas (Table 1). The highest mutation frequencies appear to be in diffuse-type gastric and infiltrative lobular breast carcinomas, with $C D H 1$ mutations detected in nearly $50 \%$ of each tumor type in some studies (Becker et al., 1994; Berx et al., 1996, 1998). The original suggestion was that CDH1 mutations in breast carcinoma were restricted to tumors of lobular type, although $C D H 1$ mutations also appear to be present in some invasive ductal carcinomas (van de Wetering et al., 2001). Somatic mutations in $C D H 1$ have been demonstrated in subsets of other malignancies, such as

endometrial and ovarian carcinomas (Risinger et al., 1994) and signet-ring cell carcinomas of the stomach (Muta et al., 1996). Somatic mutation in one $C D H 1$ allele has been shown to occur in combination with inactivation of the other allele (Berx et al., 1998). Thus, CDH1 inactivation seems to adhere to the two-hit (biallelic) model for tumorsuppressor gene inactivation (Comings, 1973; Knudson, 1985).

\section{Epigenetic Mechanisms Resulting in Cadherin Loss}

Immunohistochemical studies have demonstrated that loss of E-cadherin expression is a frequent event in many types of carcinomas (Jiang, 1996; Papadavid and Katsambas, 2001). Yet, in many cancer types where expression is frequently lost, CDH1 mutations are rare or absent (Hirohashi, 1998). Proposed epigenetic mechanisms for E-cadherin loss include alterations in the expression and/or function of the trans-acting factors that regulate $C D H 1$ gene transcription, hypermethylation of the CDH1 promoter, and chromatin-mediated effects.

Studies on prostate and breast carcinoma cell lines lacking identifiable mutations in the CDH1 gene suggest that, in some cases, transcriptional mechanisms underlie loss of E-cadherin expression. In particular, $C D H 1$ promoter-driven reporter gene constructs are active in cells with detectable 
TABLE I. Adhesive Protein Gene Alterations in Human Cancers*

\begin{tabular}{|c|c|c|c|c|}
\hline Gene & Protein & Alteration $^{\mathrm{a}}$ & Mechanism & Tumor type (mutation frequency ${ }^{b}$ ) \\
\hline \multirow[t]{3}{*}{$\mathrm{CDHI}$} & E-cadherin & Inactivation & Germline gene mutation & $\begin{array}{l}\text { Diffuse-type gastric, colorectal, breast, } \\
\text { prostate }\end{array}$ \\
\hline & & & Somatic gene mutation & $\begin{array}{l}\text { Diffuse-type gastric (50\%), lobular } \\
\text { breast ( } 50 \%) \text {, invasive ductal breast, } \\
\text { endometrial, ovarian, signet-ring cell } \\
\text { type gastric }\end{array}$ \\
\hline & & & Epigenetic & Breast, prostate, thyroid, gastric \\
\hline CTNNAI & $\alpha$-catenin & Inactivation & Gene mutation ${ }^{c}$ & $\begin{array}{l}\text { Cell lines only: lung, prostate, ovarian, } \\
\text { colon }\end{array}$ \\
\hline \multirow[t]{4}{*}{ CTNNBI } & $\beta$-catenin & Activation & Gene mutation & 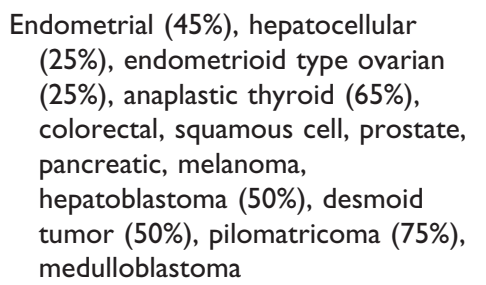 \\
\hline & & & $\begin{array}{l}\text { Other Wnt pathway defect: } \\
\text { APC mutation }\end{array}$ & $\begin{array}{l}\text { Colorectal (70-80\%), breast, gastric, } \\
\text { pancreatic, hepatocellular, ovarian, } \\
\text { medulloblastoma, hepatoblastoma, } \\
\text { desmoid tumor }\end{array}$ \\
\hline & & & $\begin{array}{l}\text { Other Wnt pathway defect: } \\
\text { AXINI or AXIN2 } \\
\text { mutation }\end{array}$ & Hepatocellular (5\%), colorectal, ovarian \\
\hline & & Inactivation & Gene mutation ${ }^{c}$ & $\begin{array}{l}\text { Cell lines only: signet-ring cell type } \\
\text { gastric }\end{array}$ \\
\hline \multirow[t]{2}{*}{ JUP } & $\gamma$-catenin & Activation & Gene mutation $^{c}$ & Cell lines only: gastric \\
\hline & & Inactivation & ND & \\
\hline CTNND I & pl $20 \mathrm{ctn}$ & Inactivation & ND & \\
\hline
\end{tabular}

*ND, not determined.

${ }^{\text {a }}$ For all proteins, loss of expression has also been documented by immunohistochemical analysis of primary tumors.

bMutations rare except when frequency noted.

'Demonstrated only in cancer cell lines.

E-cadherin protein, but not in those cells that lack E-cadherin expression (Bussemakers et al., 1994; Ji et al., 1997). Analysis of breast cancer somatic cell hybrids suggests that a dominant repression pathway extinguishes $C D H 1$ transcription through its proximal promoter (Hajra et al., 1999), and E-box elements within this region have been proposed to be critical in the silencing of $C D H 1$ transcription in cancer (Giroldi et al., 1997). A number of transcription factors may bind to $C D H 1$ E-box elements to repress transcription, including the zinc-finger transcription factors Snail (Batlle et al., 2000; Cano et

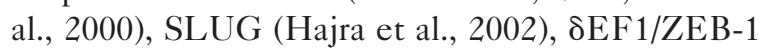
(Grooteclaes and Frisch, 2000), and SIP1/ZEB-2 (Comijn et al., 2001), and the basic helix-loophelix factor E12/E47 (Perez-Moreno et al., 2001). Increased expression of Snail has been correlated with loss of E-cadherin expression in various cancer cell lines, including those derived from human bladder, pancreas, colon, and breast carcinomas (Batlle et al., 2000), oral squamous cell carcinomas
(Yokoyama et al., 2001), and melanomas (Poser et al., 2001).

Hypermethylation of the $C D H 1$ promoter has been postulated to play a critical role in the loss of E-cadherin expression observed in some primary tumors and cell lines without identified $C D H 1 \mathrm{mu}-$ tations. CDH1 promoter hypermethylation has been reported in breast, prostate, thyroid, gastric, and other cancers (Graff et al., 1995, 1998; Yoshiura et al., 1995; Tamura et al., 2000). The finding that treatment of cell lines with demethylating agents can, in some cases, restore E-cadherin expression suggests that in some tumors, promoter hypermethylation plays an important role in silencing of CDH1 expression. $\mathrm{CDH} 1$ promoter hypermethylation has also been reported as a mechanism of inactivating the remaining wild-type $C D H 1$ allele in gastric carcinomas arising in individuals carrying germline $C D H 1$ mutations. It is worth noting that the correlation between $C D H 1$ promoter hypermethylation and loss of $C D H 1$ transcripts and E- 
cadherin protein is not exact in gastric carcinomas and perhaps other tumors (Fearon, 2000; Tamura et al., 2000). Additionally, some studies have been unable to demonstrate that demethylating agents can restore E-cadherin expression (Ji et al., 1997; Hajra et al., 1999). Thus, promoter hypermethylation may be unrelated to $C D H 1$ silencing in certain tissues and may have variable effects on $C D H 1$ silencing in other settings.

Mechanisms other than repression by certain transcription factors and promoter hypermethylation have been suggested to inactivate $C D H 1$ expression in cancer. In particular, chromatin condensation has been proposed to play a role in the silencing of $C D H 1$ expression in carcinomas (Hennig et al., 1995). The various proposed mechanisms of $C D H 1$ silencing in cancer may not be mutually exclusive. For instance, CDH1 promoter hypermethylation and chromatin remodeling may occur in concert with or as a specific consequence of the transcriptional repression effects of distinct transacting transcription factors targeted to the $C D H 1$ promoter. In support of this proposal, a strong positive association between $C D H 1$ promoter hypermethylation and increased Snail expression has been shown in some invasive ductal breast carcinomas (Cheng et al., 2001). The relative contribution and importance of specific transcription factors, promoter hypermethylation, and chromatin condensation in the silencing of $C D H 1$ expression in carcinomas remains to be clarified further, although overall the current data suggest that these processes together result in $C D H 1$ silencing.

\section{Cadherin Switching}

Notwithstanding the expansive body of data on E-cadherin loss in cancer, there are data suggesting that the inappropriate expression of nonepithelial cadherins, such as N-cadherin and cadherin-11, either in collaboration with or even instead of Ecadherin loss, may play an important role in the invasive and metastatic phenotype of cancer cells. Concomitant upregulation of $\mathrm{N}$-cadherin and/or cadherin-11 and downregulation of E-cadherin has been termed cadherin switching. Cadherin switching has been demonstrated in primary tumors, including prostate carcinomas and gastric signet-ring cell carcinomas (Shibata et al., 1996a; Tomita et al., 2000), as well as in several carcinoma-derived cell lines (Islam et al., 1996; Giroldi et al., 1999; Pishvaian et al., 1999; Bussemakers et al., 2000). In squamous cell carcinoma lines, $\mathrm{N}$-cadherin expression appears to repress E-cadherin expression, and cadherin switching from $\mathrm{E}$ - to N-cadherin is re- sponsible for a change in cellular phenotype from epithelial to scattered fibroblastic (Islam et al., 1996). Endogenous N-cadherin expression in breast cancer cell lines has been correlated with increased cellular motility and invasion, and expression of exogenous E-cadherin in one such Ncadherin-expressing line was unable to suppress the motile and invasive properties of the cells (Nieman et al., 1999). Additionally, expression of $\mathrm{N}$-cadherin was found to increase invasion and motility in two different E-cadherin-expressing cancer cell lines (Nieman et al., 1999; Hazan et al., 2000).

\section{CATENIN INACTIVATION IN CANCER}

\section{Catenin Gene Mutation}

Inactivating mutations in CTNNA1, the gene encoding $\alpha$-catenin, have been demonstrated in some lung, prostate, ovarian, and colon cancer cell lines that lack normal cadherin-dependent cell-cell adhesion (Table 1) (Shimoyama et al., 1992; Breen et al., 1993; Morton et al., 1993; Oda et al., 1993; Bullions et al., 1997; Roe et al., 1998; Vermeulen et al., 1999). Additionally, immunohistochemical analysis has demonstrated loss of $\alpha$-catenin in some primary tumors (Jiang, 1996; Papadavid and Katsambas, 2001). In selected cell lines with absent or defective $\alpha$-catenin protein, introduction of wildtype $\alpha$-catenin restores cell-cell adhesion, retards cell growth, and reduces tumorigenic growth in nude mice (Watabe et al., 1994; Ewing et al., 1995; Bullions et al., 1997). Thus, loss of $\alpha$-catenin likely accounts for the absence of calcium-dependent cell-cell adhesion in some cancers with intact Ecadherin expression, and $\alpha$-catenin can reasonably be considered an invasion suppressor molecule like E-cadherin.

Although some immunohistochemical studies on catenin expression in primary tumors have shown loss of $\beta$-catenin, $\gamma$-catenin, or p120ctn (Aberle et al., 1995; Nakanishi et al., 1997; Dillon et al., 1998; Papadavid and Katsambas, 2001), inactivating mutations in the genes encoding these catenins have been reported only rarely (Table 1). A human signet-ring gastric cancer cell line has a homozygous deletion in the $\beta$-catenin gene CTNNB1, which results in impaired cell-cell adhesion; normal cell adhesion function could be restored in this line after introduction of full-length $\beta$-catenin (Oyama et al., 1994; Kawanishi et al., 1995). In SV40-transformed 3T3 cells lacking $\gamma$-catenin expression, reintroduction of $\gamma$-catenin was found to suppress tumorigenicity (Simcha et al., 1996). The overall 
paucity of inactivating alterations in $\beta$-catenin and $\gamma$-catenin could be attributable to the possibility that the two proteins have largely redundant functions in linking E-cadherin to $\alpha$-catenin in many epithelial cell types. Hence, the loss of one of the proteins would be insufficient to disrupt cell-cell adhesion. Moreover, as reviewed below, the infrequent inactivation of $\beta$-catenin and possibly also $\gamma$-catenin in cancer cells may also be related to their positive roles in Wnt signaling or other growth-regulatory pathways.

\section{Post-Transcriptional Effects on Catenin Function}

The cadherin-catenin adhesion complex is regulated by post-translational mechanisms, and perturbations of this regulation may be important in some human cancers. Tyrosine phosphorylation of catenins has been shown to decrease cell-cell adhesiveness, whereas dephosphorylation appears to increase adhesion (Hirohashi, 1998). $\beta$-Catenin, $\gamma$-catenin, and p120ctn all demonstrate tyrosine phosphorylation by cytoplasmic protein kinases of the Src family and by transmembrane receptor tyrosine kinases (R'TKs). Expression of the $v$-Src oncogene leads to tyrosine phosphorylation of $\beta$-catenin and results in decreased cadherin-mediated adhesion, epithelial dedifferentiation, and increased cellular invasion (Matsuyoshi et al., 1992; Behrens et al., 1993). Although there is a strong correlation between $\beta$-catenin tyrosine phosphorylation and disruption of cadherin-catenin cell-cell adhesion, it is not clear whether the tyrosine phosphorylation of $\beta$-catenin is required for $v-S r c-$ mediated disruption of adhesion (Takeda et al., 1995). Evidence in favor of an important role for Src family phosphorylation of catenins in transformation comes from mutational studies of the Src protein p60, which demonstrated that p120ctn and $\beta$-catenin are phosphorylated only by kinase-active, transformation-capable p60, and not by transformation-defective p60 (Reynolds et al., 1989; Hamaguchi et al., 1993). At present, although the correlations observed are suggestive, it remains uncertain whether oncogenic alterations in cytoplasmic protein kinases directly perturb cell-cell adhesion mediated by the cadherin-catenin complex.

Similar to cytoplasmic tyrosine kinases, R'TKs may also disrupt cellular adhesion by phosphorylation of catenins. Both hepatocyte growth factor/ scatter factor and epidermal growth factor (EGF) induce phosphorylation of $\beta$-catenin and $\gamma$-catenin in human carcinoma cell lines (Shibamoto et al.,
1994). EGF, platelet-derived growth factor, and colony-stimulating factor all stimulate tyrosine phosphorylation of p120ctn (Downing and Reynolds, 1991; Kanner et al., 1991). Two R'TKs that are overexpressed in human carcinomas, EGF receptor and ERBB2 (HER2/NEU), have been shown to interact directly with $\beta$-catenin (Hoschuetzky et al., 1994; Ochiai et al., 1994; Kanai et al., 1995). In carcinoma cell lines, EGF treatment causes catenin phosphorylation, alterations in the subcellular localization of cadherin, and disruption of the cadherin-catenin linkage to the actin cytoskeleton (Shiozaki et al., 1995; Hazan and Norton, 1998). A deleted form of $\beta$-catenin, which binds to ERBB2 but not to E-cadherin, was shown to act in a dominant-negative manner to prevent ERBB2's interaction with endogenous $\beta$-catenin and to inhibit cancer cell invasion and metastasis (Shibata et al., 1996b), consistent with the notion that ERBB2 modulates cadherin-catenin-mediated adhesion in vivo.

In addition to the potential role of kinases in post-transcriptional regulation of the cadherincatenin complex, GTPases also appear to play a possible role in regulating cadherin-catenin function. Studies indicate that Rho-family small GTPases, including proteins Rho, Rac, and Cdc42, function in cadherin-mediated cell-cell adhesion. These GTPases cycle between an inactive, GDP-bound form and an active, GTPbound form. Rho and Rac are required for the formation of cadherin-based cell-cell adhesion contacts (Braga et al., 1997; Takaishi et al., 1997). A recent report offers some insight into how Rho may be mechanistically linked to the functioning of the cadherin-catenin complex. Specifically, p120ctn was shown to bind cadherins and RhoA in a mutually exclusive manner, binding to inactive RhoA and retaining it in an inactive state (Anastasiadis et al., 2000), thus inhibiting downstream signaling believed to promote strong adhesion. p120ctn binding to cadherins also strengthens cellular adhesion; thus, a shift from p120ctn-cadherin binding to p120ctn-RhoA binding could perhaps decrease cadherin-catenin-mediated adhesion by multiple mechanisms.

Rho-family GTPases Cdc42 and Rac1 also directly regulate E-cadherin activity (Fig. 2) (Kaibuchi et al., 1999). When Cdc42 and Rac1 are in the inactive form, their effector protein, IQGAP1, binds both to the cytoplasmic domain of E-cadherin and to $\beta$-catenin, apparently causing dissociation of $\alpha$-catenin from the cadherin-catenin complex and a decrease in cell adhesion (Kuroda et al., 


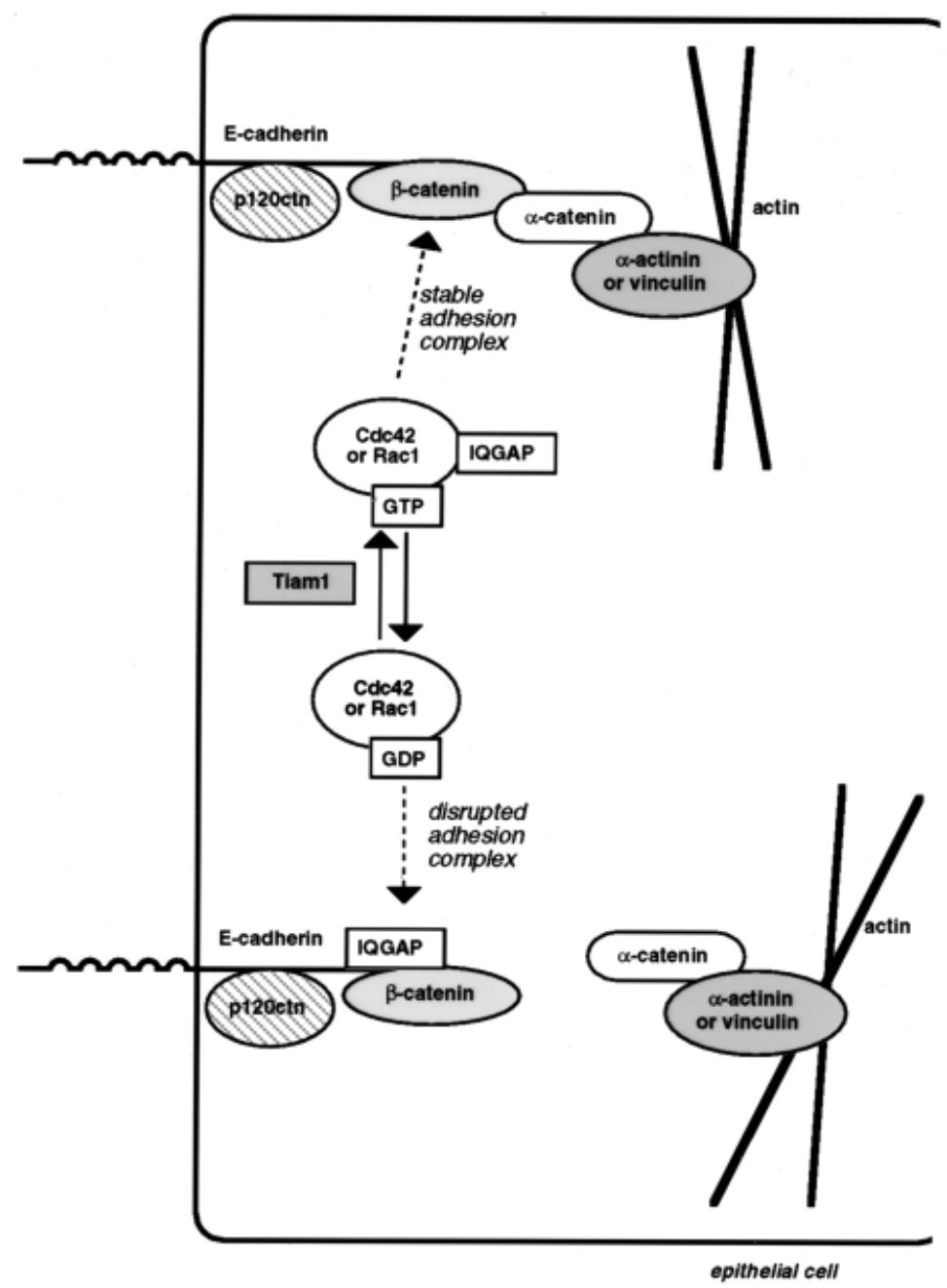

Figure 2. GTPase/IQGAP effects on the cadherin-catenin adhesion complex. When Cdc42 and Racl are in the active form, they interact with their effector protein IQGAPI to sequester it from the cadherincatenin adhesion complex, resulting in complex stabilization. When the GTPases are in the inactive form, IQGAPI binds both to the cytoplas-

1998; Fukata et al., 1999). In contrast, when Cdc42 and Rac1 are in the active form, they interact with IQGAP1, thus preventing it from interacting with $\beta$-catenin, and the cadherin-catenin complex is stabilized. In the case of the exchange factor Tiam-1, by stimulating the formation of active Rac1, Tiam-1 is likely to increase E-cadherin-mediated cell-cell adhesion. This may possibly explain Tiam-1's previously identified ability to inhibit invasion of epithelial cells (Hordijk et al., 1997). This pathway may be important in a considerable fraction of human cancers, given that oncogenic Ras has been shown to downregulate both Rac1 and Tiam-1 and to induce an epithelial-tomesenchymal transition in cell phenotype (Zondag et al., 2000). mic domain of E-cadherin and to $\beta$-catenin, resulting in disruption of the adhesion complex. Tiam- $I$ is a guanine nucleotide exchange factor that stimulates the formation of active Racl, thus stabilizing the cadherincatenin complex.

\section{ACTIVATION OF CATENINS IN CANCER}

\section{The Wnt Signaling Pathway}

In addition to its well-defined role in cellular adhesion, $\beta$-catenin functions in the Wnt signaling pathway (Fig. 3) (Polakis, 2000). Consistent with its ostensibly independent functions in cell adhesion and signal transduction, at least two distinct pools of $\beta$-catenin exist in cells, a cadherin-associated (cell membrane-associated) pool and a pool involved in Wnt signaling and gene transcription. The $\beta$-catenin pool that functions in Wnt signaling and gene transcription is regulated in part by the adenomatous polyposis coli (APC) tumor-suppressor protein, AXIN proteins, and glycogen synthase kinase $3 \beta$ (GSK3 $\beta$ ) (Polakis, 2000). In the absence 
A.

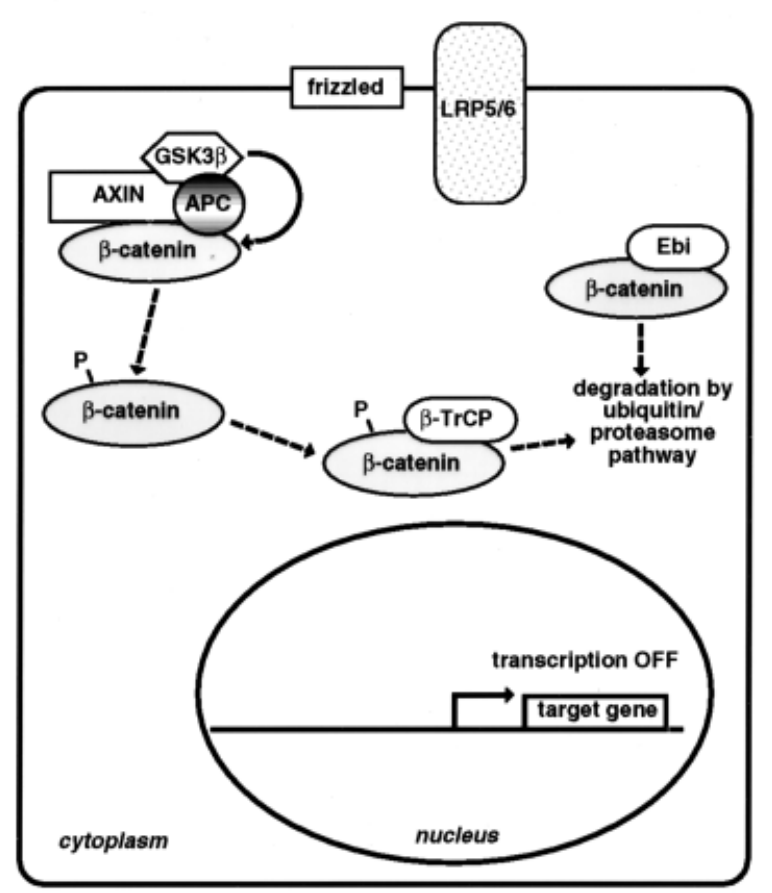

Figure 3. The canonical Wnt signaling pathway. A: $\beta$-Catenin is degraded in the absence of Wnt signals. In the absence of signals from upstream factors, such as those attributed to Wnt interactions with the Frizzled-LRP5/6 receptor complex, GSK3 $\beta$ forms a multiprotein complex with the APC tumor suppressor, $\beta$-catenin, and AXINI or AXIN2 (also called axil or conductin). GSK3 $\beta$ phosphorylates $\beta$-catenin on likely multiple serine and threonine residues in its $\mathrm{N}$-terminal domain, thus targeting $\beta$-catenin for recognition by specific ubiquitination factors, including the F-box protein $\beta$-TrCP, and subsequent degradation by the proteasome. Nonphosphorylated $\beta$-catenin may also be degraded by the ubiquitin-proteasome pathway, although, in this case, the

of a Wnt signal, $\beta$-catenin is bound by AXIN and APC and phosphorylated by GSK3 $\beta$ at one or more serine or threonine residues in its amino $(\mathrm{N})$-terminal domain. The N-terminally phosphorylated $\beta$-catenin is then recognized and ubiquitinated by a multiprotein complex that includes the F-box protein $\beta$-TrCP, with resultant degradation of the ubiquitinated $\beta$-catenin by the proteasome ( $\mathrm{Po}_{\mathrm{O}}$ lakis, 2001). Additionally, nonphosphorylated $\beta$-catenin can be degraded by the ubiquitin-proteasome pathway, utilizing a unique protein complex that includes the F-box protein Ebi rather than $\beta$-TrCP (Polakis, 2001). Wnt signals activate pathways that lead to inhibition of GSK3$\beta$ activity and sequestration of AXIN at the cell membrane by LRP5/6, both of which contribute to the resultant stabilization of $\beta$-catenin (Nusse, 2001). The stabilization of $\beta$-catenin leads to its enhanced interaction with members of the T-cell factor/lymphoid enhancer factor (Tcf/Lef) family of transcription factors (Behrens et al., 1996). $\beta$-Catenin's interac-
B.

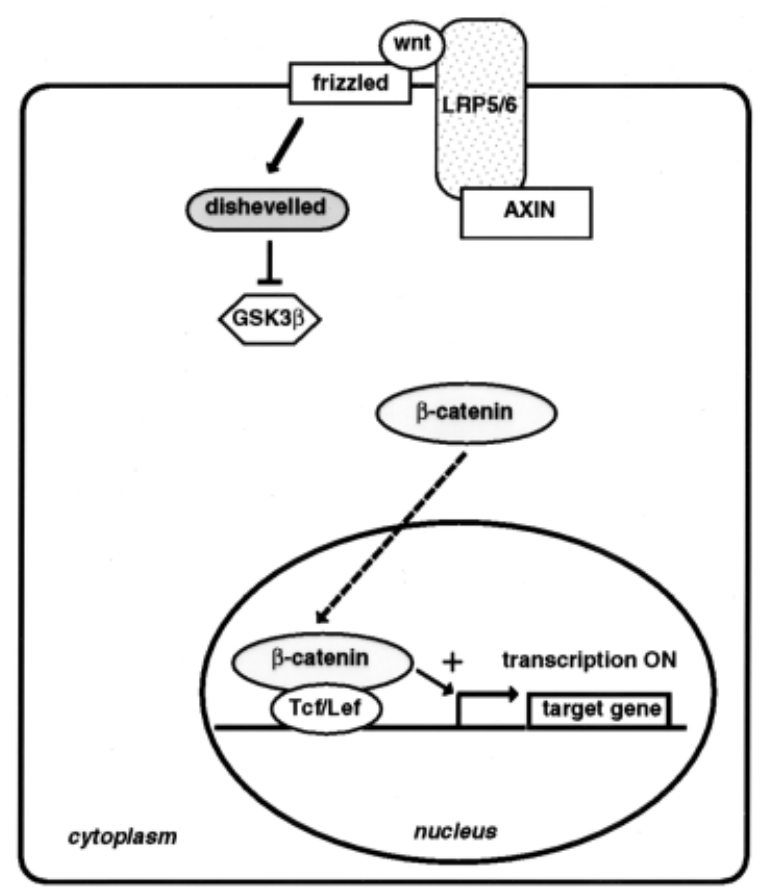

ubiquitination complex contains the F-box protein Ebi and other unique factors. B: Wnt signals result in $\beta$-catenin stabilization and the formation of $\beta$-catenin-Tcf/Lef complexes. When Wnt signals through the Frizzled-LRP5/6 receptor complex, dishevelled is activated and inhibits the function of GSK3 $\beta$. Inhibition of GSK3 $\beta$ results in decreased phosphorylation of $\beta$-catenin and subsequent $\beta$-catenin stabilization. Additionally, Wnt signaling recruits AXIN to the cytoplasmic domain of LRP5/6, which also contributes to the stabilization of $\beta$-catenin. The elevated levels of $\beta$-catenin appear to lead to its increased complex formation with members of the Tcf/Lef transcription factor family and resultant effects on the transcription of $\beta$-catenin-Tcf/Lef target genes.

tion with Tcf/Lef proteins alters their transcriptional activity, resulting, in many cases, in activation of genes with Tcf/Lef binding sites in their regulatory regions.

\section{Mutational Deregulation of Catenin Function}

Deregulation of the Wnt pathway has been shown to occur by several different mutational mechanisms in human cancers (Table 1) (Polakis, 2000). Mutations in the CTNNB1 gene in the sequences encoding the critical serines and threonines at $\beta$-catenin's N-terminus have been seen in many cancer types, including melanoma, colorectal carcinoma, hepatocellular carcinoma, medulloblastoma, hepatoblastoma, endometrial carcinoma, squamous cell carcinoma of the head and neck, prostate carcinoma, desmoid tumors, pilomatricomas, pancreatic carcinoma, ovarian carcinoma, and thyroid carcinoma (Morin, 1999; Polakis, 2000). These mutations render the mutant $\beta$-catenin proteins resistant to phosphorylation by GSK3 $\beta$. In- 
terestingly, it does not appear that cadherin-catenin-mediated adhesion is adversely affected by the oncogenic mutations in $\beta$-catenin. Inactivating mutations in the $A P C$ tumor-suppressor gene appear to inhibit formation of the functional GSK3 $\beta / \mathrm{APC} /$ AXIN/ $\beta$-catenin complex as well as interfere with APC's function in the export of $\beta$-catenin from the nucleus (Henderson, 2000; Rosin-Arbesfeld et al., 2000). APC mutations have been found in roughly $70-80 \%$ of colorectal carcinomas and a subset of other cancers, including gastric, pancreatic, hepatocellular, breast, and ovarian carcinomas, medulloblastomas, desmoid tumors, and hepatoblastomas (Polakis, 1995; Laurent-Puig et al., 1998). Similar to $A P C$ mutations, inactivating mutations in $A X I N 1$ or $A X I N 2$ in cancer cells appear to stabilize $\beta$-catenin (Peifer and Polakis, 2000). Thus far, AXIN1 and AXIN2 mutations have been seen in some hepatocellular (Satoh et al., 2000), colorectal (Liu et al., 2000), and ovarian (Wu et al., 2001) carcinomas.

The presumed critical consequence of the activating mutations in $\beta$-catenin or the inactivating mutations in APC and AXIN is elevated levels of $\beta$-catenin in the cytoplasm and the nucleus. The elevated levels of $\beta$-catenin lead to the constitutive formation of $\beta$-catenin-Tcf/Lef complexes and altered transcription of Tcf/Lef target genes. Proposed Tcf/Lef-regulated target genes in cancer cells include MYC (He et al., 1998), cyclin D1 (Shtutman et al., 1999; Tetsu and McCormick, 1999), matrix metalloproteinase 7 (MMP-7) (Brabletz et al., 1999; Crawford et al., 1999), Tcf7 (Roose et al., 1999), Lef-1 (Hovanes et al., 2001), peroxisome proliferator-activated receptor delta (PPAR $\delta$ ) (He et al., 1999), and gastrin (Koh et al., 2000).

A number of lines of evidence indicate that $\gamma$-catenin may also function in the Wnt signaling pathway (Barker and Clevers, 2000; Zhurinsky et al., 2000). To date, there have been no reports of $\gamma$-catenin mutations in primary human tumors, although a missense mutation at one of the conserved serine residues in $\gamma$-catenin's $\mathrm{N}$-terminus was found in a gastric cancer cell line that showed deregulated Tcf/Lef transcriptional activity but no mutations in $\beta$-catenin (Caca et al., 1999). Although conclusive data establishing that $\gamma$-catenin functions as an oncogene in human cancer have yet to be obtained, there are some additional data that implicate deregulation of $\gamma$-catenin in cancer. First, like $\beta$-catenin, $\gamma$-catenin binds to the APC and AXIN proteins (Hulsken et al., 1994; Shibata et al., 1994; Rubinfeld et al., 1995; Kodama et al., 1999). Second, akin to some of the effects seen on $\beta$-catenin levels and localization in cells with APC de- fects, APC inactivation in colon cancer cells leads to altered regulation of $\gamma$-catenin (Kolligs et al., 2000). Third, upon its overexpression in the RK3E in vitro model system, wild-type $\gamma$-catenin can promote neoplastic transformation (Kolligs et al., 2000).

Interestingly, although mutations in $\beta$-catenin's $\mathrm{N}$-terminus are required to activate its oncogenic potential and wild-type $\beta$-catenin has no transforming activity in the RK3E transformation model, wild-type $\gamma$-catenin is transforming in RK3E, and mutations in the conserved $\mathrm{N}$-terminus of $\gamma$-catenin do little to enhance its transforming activity (Kolligs et al., 2000). This observation might offer some clues to why mutations in $\gamma$-catenin are rare in cancer. Further work will be needed to demonstrate that $\gamma$-catenin plays an important role in cancer, although, given most of the observations to date, it might be interesting to determine whether any tumors demonstrate genomic amplification of $\gamma$-catenin as a mechanism for increased $\gamma$-cateninTcf/Lef target gene activation. It is worth noting that $\gamma$-catenin appears to have some effects on Tcf/Lef transcriptional regulation distinct from those seen with $\beta$-catenin (Kolligs et al., 2000), consistent with the notion that the functions of $\beta$ and $\gamma$-catenin are not equivalent in either signaling or cell-cell adhesion. Deregulation of both proteins may yield cooperative effects and may be important in the genesis of certain cancers, such as those in which the APG or AXIN proteins are defective.

\section{CONTRIBUTION OF CADHERIN-CATENIN DEFECTS IN CANCER}

\section{Role of Loss-of-Function Defects in E-Cadherin and Catenin}

In several cancer types, loss of either E-cadherin or $\alpha$-catenin has been correlated with tumor dedifferentiation, infiltrative growth, lymph node metastasis, and poorer patient prognosis. Additionally, in in vitro models, loss of E-cadherin function increases invasive growth, and reintroduction of functional E-cadherin into cells with endogenous E-cadherin defects suppresses their invasive behavior (Behrens et al., 1989; Vleminckx et al., 1991). A simple model might be that the cadherincatenin complex has a purely mechanical function by attaching neighboring cells to one another. However, there is increasing evidence that the cadherin-catenin complex also functions in signaling. Unfortunately, the signaling pathways and proteins specifically modulated by cadherin-dependent ad- 
hesion are not yet well delineated, although a few clues seem to have emerged. For example, with respect to effects on gene expression, the E-cadherin binding protein p120ctn has been shown to interact with the zinc-finger transcription finger Kaiso (Daniel and Reynolds, 1999). Therefore, alterations in gene transcription after loss of E-cadherin may be mediated through Kaiso.

In addition, whereas tyrosine phosphorylation of catenins is likely to play an important role in modulating cadherin-catenin complexes, defects in the expression of E-cadherin or the catenins may lead, in turn, to altered tyrosine kinase localization and/or function, resulting in aberrant phosphorylation of various protein substrates. Because protein tyrosine phosphatases have also been shown to interact with the cadherin-catenin adhesion complex (Brady-Kalnay et al., 1995; Balsamo et al., 1996; Fuchs et al., 1996; Kypta et al., 1996), defects in cadherin and/or catenin expression may alter the function of tyrosine phosphatases and their substrates as well. Nevertheless, whereas the possible effects of cadherin-catenin inactivation on tyrosine kinase and phosphatase function are of some interest, vigorous approaches and thoughtful interpretation of the data will be critical to define the specificity of the effects on cancer cell phenotype resulting directly from the alterations in cadherincatenin expression and function. Factors contributing to this view are the many and diverse cellular functions of tyrosine kinases and phosphatases (Pawson and Nash, 2000) and the possibility of bidirectional interactions between these factors and the cadherin-catenin complex. As such, it will be critical to establish definitively that altered cadherin-catenin function has a contributory role in modulating tyrosine phosphorylation and the cancer cell phenotype.

Although $\beta$-catenin functions as a transcription factor, inactivation of E-cadherin and the resultant disruption of cellular adhesion do not appear to result in significant increases in the levels of free $\beta$-catenin and increased transcription of Tcf/Lef target genes. Introduction of E-cadherin into a cell line lacking E-cadherin and demonstrating constitutively active $\beta$-catenin-Tcf/Lef signaling can help sequester $\beta$-catenin and reduce Tcf/Lef transcription (Gottardi et al., 2001). However, the converse is not true, given that loss of endogenous E-cadherin expression does not result in constitutive $\beta$-catenin-Tcf/Lef transcriptional activation (Caca et al., 1999; van de Wetering et al., 2001). These latter observations suggest that a functional $\beta$-catenin phosphorylation and degradation path- way is sufficient to remove excess $\beta$-catenin from the cytoplasm after loss of E-cadherin, thus preventing potential oncogenic signaling.

\section{Role of Cadherin Switching}

Expression of nonepithelial cadherins or even inappropriate expression of epithelial cadherins on carcinoma cells, perhaps those characteristic of other epithelial cell types or lineages, may facilitate the invasive properties of the neoplastic cells through novel homotypic interactions with cadherin molecules expressed by stromal cells and/or heterologous epithelial cells. This has been a proposed mechanism for cellular invasion by N-cadherin-expressing breast cancer cells (Hazan et al., 1997) and for invasion by gastric carcinomas and breast carcinomas with elevated cadherin-11 expression (Shibata et al., 1996a; Pishvaian et al., 1999). Of note, it has been reported that the inappropriate expression of $\mathrm{N}$-cadherin can increase invasion into an extracellular matrix in the absence of other cell types (Nieman et al., 1999), suggesting a possible role for activation of other signaling pathways, perhaps including altered integrin function, in the increased motility of $\mathrm{N}$-cadherin-expressing cells. Given the distinct roles of E-cadherin vs. $\mathrm{N}$-cadherin and cadherin-11 in homotypic adhesive interactions between epithelial vs. nonepithelial cells, respectively, both the loss of E-cadherin expression and the gain of $\mathrm{N}$-cadherin or cadherin-11 expression are likely to be important in modulating the adhesive properties of the carcinoma cells. If specific transcription factors that facilitate cadherin switching are identified, it will further support this model and its importance.

\section{Role of Gain-of-Function Alterations in the Catenins}

As reviewed above, activating mutations in the gene encoding $\beta$-catenin or inactivating mutations in $A P C, A X I N 1$, or $A X I N 2$ lead to the deregulation of $\beta$-catenin levels and localization and the constitutive interaction of $\beta$-catenin with Tcf/Lef transcription factors. Several genes likely to be regulated directly by the $\beta$-catenin-Tcf/Lef complex have been identified, and it is believed that a number of them may play a critical role in aspects of the cancer phenotype. As mentioned previously, among the candidate genes are $M Y C$ (He et al., 1998), cyclin D1 (Shtutman et al., 1999; Tetsu and McCormick, 1999), matrix metalloproteinase 7 (MMP-7) (Brabletz et al., 1999; Crawford et al., 1999), Tcf7 (Roose et al., 1999), Lef-1 (Hovanes et al., 2001), peroxisome proliferator-activated receptor 
delta (PPAR $\delta)$ (He et al., 1999), and gastrin (Koh et al., 2000). Some of these genes are discussed further below.

Both $M Y G$ and cyclin D1 are well-characterized oncogenes that are themselves frequently altered in human carcinomas. Presumably, their roles in cancers with defects in $\beta$-catenin regulation might be akin to the roles they play in other cancer types, where they are affected by gain-offunction mutations. These roles include the well-defined effects of the c-Myc protein on the transcription of genes involved in cell proliferation and cell growth and the effects of cyclin D1 on cell-cycle progression. The matrix metalloproteinases (MMPs) were first defined in large part because of their roles as connective tissue-degrading enzymes produced by human tumors. The MMPs function in basement-membrane and connective-tissue destruction and may contribute to tumor progression, invasion, and metastasis by this activity (MacDougall and Matrisian, 1995). MMPs may also have the ability to cleave and inactivate transmembrane growth-inhibitory proteins and/or secreted growth-inhibitory factors. In addition, MMPs may cleave and activate different transmembrane, cell-associated, or secreted proteins that stimulate cell growth. All of these functions could contribute to the invasive and metastatic properties of tumor cells. MMP-7 appears to be upregulated in colon tumors at both early and later stages of tumorigenesis (Wilson and Matrisian, 1996), and evidence of MMP-7 as a specific target of $\beta$-catenin-Tcf/Lef transcription (Brabletz et al., 1999; Crawford et al., 1999) is supported by other findings. For example, elevated MMP-7 expression has been observed in almost all (88\%) intestinal tumors arising in the $A P C^{\text {Min }}$ mouse model for familial adenomatous polyposis, in which there is an inactivating germline mutation in one of the two murine homologs of $A P C$ (Wilson et al., 1997). Additionally, mice that carry the $A P C^{\text {Min }}$ allele as well as targeted deletions of both $M M P-7$ alleles show a marked suppression of intestinal tumor formation compared to the situation in $A P C^{\text {Min }}$ mice carrying wild-type $M M P-7$ alleles (Wilson et al., 1997). Overall, the data strongly support the notion that $M M P-7$ is a direct target of $\beta$-cateninTcf/Lef transcriptional activation and imply that MMP-7 likely has important functions in tumors arising as a result of $\beta$-catenin deregulation.

The genes Tcf7 and Lef-1, encoding the Tcf1 and Lef-1 protein products, respectively, are likely targets of $\beta$-catenin signaling based on their potential to function in cellular feedback loops. Interestingly, each of these genes encodes multiple isoforms of the proteins, some of which can bind $\beta$-catenin and facilitate transcriptional activation of Tcf/Lef-regulated target genes, and others that cannot bind $\beta$-catenin and thus act in a dominantnegative fashion. In the case of $T c f 7$, these dominant-negative isoforms that do not bind $\beta$-catenin are specifically upregulated by the $\beta$-catenin-Tcf/ Lef complex, probably in an attempt to turn off $\beta$-catenin-Tcf/Lef signaling, given that the isoforms compete for Tcf/Lef DNA-binding sites in the regulatory regions of target genes (Roose et al., 1999). In contrast to the situation with the Tcf7 gene and dominant-negative Tcf1 isoform induction, Lef- 1 isoforms that can bind $\beta$-catenin appear to be selectively upregulated by the $\beta$-cateninTcf/Lef transcription complex, thus resulting in a positive feedback loop in which the oncogenic signal may, in fact, be amplified (Hovanes et al., 2001). The specific contributions of the seemingly competing effects of the activation of Tcf1 and Lef-1 isoforms by $\beta$-catenin-Tcf/Lef transcription in normal and neoplastic tissues remain largely undefined at present.

As discussed above, some evidence has been obtained that defects in $\gamma$-catenin regulation may also be a factor in cancer, such as in colon and other cancers with APC or AXIN defects. Whereas both $\beta$ - and $\gamma$-catenin appear to require Tcf/Lef function for neoplastic transformation and a number of target genes may be activated similarly as a consequence of either $\beta$ - or $\gamma$-catenin deregulation (Kolligs et al., 1999, 2000), some differences appear to exist in their transcriptional targets. Specifically, at least in some cell types, $\gamma$-catenin may activate the $M Y C$ gene far more potently than does $\beta$-catenin (Kolligs et al., 2000). The further characterization of both common and unique gene targets of the two proteins should help to clarify the mechanisms by which each contributes to cancer development.

\section{SUMMARY AND FUTURE DIRECTIONS}

Three distinctive consequences of alterations in the cadherin-catenin complex arise from the defects commonly seen in cancer cells. These consequences are loss of adhesion complex function, most commonly attributed to inactivation of E-cadherin or $\alpha$-catenin expression or function; aberrant cadherin-catenin complex formation and function arising from cadherin switching; and altered cell signaling and target gene transcription resulting from deregulation of $\beta$-cate- 
nin and also possibly $\gamma$-catenin after gain-offunction defects in $\beta$-catenin or loss-of-function defects in APG or the AXINs. The role of cellsignaling proteins that associate with the cadherin-catenin complex is an important area for further study, particularly with respect to the specific signaling alterations seen after disruption of the adhesion complex. The mechanism and significance of cadherin switching also require further investigation. The finding that chromosome arm 16q contains genes encoding several classical cadherin-family members, including E-cadherin, cadherin-11, P-cadherin, and H-cadherin (Lee, 1996; Kremmidiotis et al., 1998), presents the interesting question of whether there is concerted regulation of these genes in cadherin switching. Finally, it seems likely that novel catenin-Tcf/Lef-regulated genes will continue to be identified in the near future, and thus the specific effects attributable to $\beta$-catenin vs. $\gamma$-catenin deregulation in cancer will be better understood. There is no question that changes in the cadherin-catenin complex are important in carcinoma development and progression. The hope is that further studies will soon offer a fuller picture of the molecular details and consequences of the alterations.

\section{REFERENCES}

Aberle H, Bierkamp C, Torchard D, Serova O, Wagner T, Natt E, Wirsching J, Heidkamper C, Montagna M, Lynch HT, Lenoir GM, Scherer G, Feunteun J, Kemler R. 1995. The human plakoglobin gene localizes on chromosome 17 q21 and is subjected to loss of heterozygosity in breast and ovarian cancers. Proc Natl Acad Sci USA 92:6384-6388.

Anastasiadis PZ, Moon SY, Thoreson MA, Mariner DJ, Crawford HC, Zheng Y, Reynolds AB. 2000. Inhibition of RhoA by p120 catenin. Nat Cell Biol 2:637-644.

Balsamo J, Leung T, Ernst H, Zanin MK, Hoffman S, Lilien J. 1996. Regulated binding of PTP1B-like phosphatase to N-cadherin: control of cadherin-mediated adhesion by dephosphorylation of $\beta$-catenin. J Cell Biol 134:801-813.

Barker N, Clevers H. 2000. Catenins, wnt signaling and cancer. Bioessays 22:961-965.

Batlle E, Sancho E, Franci C, Dominguez D, Monfar M, Baulida J, Garcia de Herreros A. 2000. The transcription factor Snail is a repressor of E-cadherin gene expression in epithelial tumour cells. Nat Cell Biol 2:84-89.

Becker KF, Atkinson MJ, Reich U, Becker I, Nekarda H, Siewert JR, Hofler H. 1994. E-cadherin gene mutations provide clues to diffuse type gastric carcinomas. Cancer Res 54:3845-3852.

Behrens J, Mareel MM, Van Roy FM, Birchmeier W. 1989. Dissecting tumor cell invasion: epithelial cells acquire invasive properties after the loss of uvomorulin-mediated cell-cell adhesion. J Cell Biol 108:2435-2447.

Behrens J, Vakaet L, Friis R, Winterhager E, van Roy F, Mareel MM, Birchmeier W. 1993. Loss of epithelial cell differentiation and gain of invasiveness correlates with tyrosine phosphorylation of the E-cadherin/ $\beta$-catenin complex in cells transformed with a temperature-sensitive v-SRC gene. J Cell Biol 120:757-766.

Behrens J, von Kreis JP, Kuhl M, Bruhn L, Wedlich D, Grosschedl R, Birchmeier W. 1996. Functional interaction of $\beta$-catenin with the transcription factor LEF-1. Nature 382:638-642.

Berx G, Cleton-Jansen AM, Strumane K, de Leeuw WJ, Nollet F, van Roy F, Cornelisse C. 1996. E-cadherin is inactivated in a majority of invasive human lobular breast cancers by truncation mutations throughout its extracellular domain. Oncogene 13:1919-1925.

Berx G, Becker K-F, Hofler H, van Roy F. 1998. Mutations of the human E-cadherin $(C D H 1)$ gene. Hum Mutat 12:226-237.

Brabletz T, Jung A, Dag S, Hlubek F, Kirchner T. 1999. $\beta$-Catenin regulates the expression of the matrix metalloproteinase-7 in human colorectal cancer. Am J Pathol 155:1033-1038.

Brady-Kalnay SM, Rimm DL, Tonks NK. 1995. Receptor protein tyrosine phosphatase PTP $\mu$ associates with cadherins and catenins in vivo. J Cell Biol 130:977-986.

Braga VM, Machesky LM, Hall A, Hotchin NA. 1997. The small GTPases Rho and Rac are required for the establishment of cadherin-dependent cell-cell contacts. J Cell Biol 137:1421-1431.

Breen E, Clarke A, Steele GJ, Mercurio AM. 1993. Poorly differentiated colon carcinoma cell lines deficient in $\alpha$-catenin expression express high levels of surface E-cadherin but lack $\mathrm{Ca}^{2+}$-dependent cell-cell adhesion. Cell Adhes Commun 1:239-250.

Bullions LC, Notterman DA, Chung LS, Levine AJ. 1997. Expression of wild-type $\alpha$-catenin protein in cells with a mutant $\alpha$-catenin gene restores both growth regulation and tumor suppressor activities. Mol Cell Biol 17:4501-4508.

Bussemakers MJ, Van Bokhoven A, Tomita K, Jansen CF, Schalken JA. 2000. Complex cadherin expression in human prostate cancer cells. Int J Cancer 85:446-450.

Bussemakers MJG, Giroldi LA, van Bokhoven A, Schalken JA. 1994. Transcriptional regulation of the human E-cadherin gene in human prostate cancer cell lines. Biochem Biophys Res Commun 203:1284-1290.

Caca K, Kolligs FT, Ji X, Hayes M, Qian J, Yahanda A, Rimm DL, Costa J, Fearon ER. 1999. $\beta$ - and $\gamma$-Catenin mutations, but not E-cadherin inactivation, underlie T-cell factor/lymphoid enhancer factor transcriptional deregulation in gastric and pancreatic cancer. Cell Growth Differ 10:369-376.

Cano A, Perez-Moreno MA, Rodrigo I, Locascio A, Blanco MJ, del Barrio MG, Portillo F, Nieto MA. 2000. The transcription factor Snail controls epithelial-mesenchymal transitions by repressing E-cadherin expression. Nat Cell Biol 2:76-83.

Cheng CW, Wu PE, Yu JC, Huang CS, Yue CT, Wu CW, Shen CY. 2001. Mechanisms of inactivation of E-cadherin in breast carcinoma: modification of the two-hit hypothesis of tumor suppressor gene. Oncogene 20:3814-3823.

Comijn J, Berx G, Vermassen P, Verschueren K, van Grunsven L, Bruyneel E, Mareel M, Huylebroeck D, van Roy F. 2001. The two-handed $\mathrm{E}$ box binding zinc finger protein SIP1 downregulates E-cadherin and induces invasion. Mol Cell 7:1267-1278.

Comings DE. 1973. A general theory of carcinogenesis. Proc Natl Acad Sci USA 70:3324-3328.

Crawford HC, Fingleton BM, Rudolph-Owen LA, Goss KJ, Rubinfeld B, Polakis P, Matrisian LM. 1999. The metalloproteinase matrilysin is a target of $\beta$-catenin transactivation in intestinal tumors. Oncogene 18:2883-2891.

Daniel JM, Reynolds AB. 1999. The catenin p120(ctn) interacts with Kaiso, a novel BTB/POZ domain zinc finger transcription factor. Mol Cell Biol 19:3614-3623.

Dillon DA, D’Aquila T, Reynolds AB, Fearon ER, Rimm DL. 1998. The expression of p120ctn protein in breast cancer is independent of $\alpha$ - and $\beta$-catenin and E-cadherin. Am J Pathol 152:75-82.

Downing JR, Reynolds AB. 1991. PDGF, CSF-1, and EGF induce tyrosine phosphorylation of p120, a pp60src transformation-associated substrate. Oncogene 6:607-613.

Ewing CM, Ru N, Morton RA, Robinson JC, Wheelock MJ, Johnson KR, Carrett JC, Isaacs WB. 1995. Chromosome 5 suppresses tumorigenicity of PC3 prostate cancer cells: correlation with reexpression of $\alpha$-catenin and restoration of E-cadherin function. Cancer Res 55:4813-4817.

Fearon ER. 2000. BRCA1 and E-cadherin promoter hypermethylation and gene inactivation in cancer: association or mechanism? J Natl Cancer Inst 92:515-517.

Fuchs M, Muller T, Lerch MM, Ullrich A. 1996. Association of human protein-tyrosine phosphatase kappa with members of the armadillo family. J Biol Chem 271:16712-16719.

Fukata M, Kuroda S, Nakagawa M, Kawajiri A, Itoh N, Shoji I, Matsuura Y, Yonehara S, Fujisawa H, Kikuchi A, Kaibuchi K. 1999. Cdc42 and Rac1 regulate the interaction of IQGAP1 with B-catenin. J Biol Chem 274:26044-26050.

Gayther SA, Gorringe KL, Ramus SJ, Huntsman D, Roviello F, Grehan N, Machado JC, Pinto E, Seruca R, Halling K, MacLeod P, Powell SM, Jackson CE, Ponder BAJ, Caldas C. 1998. Identification of germ-line E-cadherin mutations in gastric cancer families of European origin. Cancer Res 58:4086-4089. 
Giroldi LA, Bringuier P-P, de Weijert M, Jansen C, van Bokhoven A, Schalken JA. 1997. Role of $\mathrm{E}$ boxes in the repression of E-cadherin expression. Biochem Biophys Res Commun 241:453458.

Giroldi LA, Bringuier PP, Shimazui T, Jansen K, Schalken JA. 1999. Changes in cadherin-catenin complexes in the progression of human bladder carcinoma. Int J Cancer 82:70-76.

Gottardi CJ, Wong E, Gumbiner BM. 2001. E-cadherin suppresses cellular transformation by inhibiting $\beta$-catenin signaling in an adhesion-independent manner. J Cell Biol 153:1049-1060.

Graff JR, Herman JG, Lapidus RG, Chopra H, Xu R, Jarrard DF, Isaacs WB, Pitha PM, Davidson NE, Baylin SB. 1995. E-cadherin expression is silenced by DNA hypermethylation in human breast and prostate carcinomas. Cancer Res 55:5195-5199.

Graff JR, Greenberg VE, Herman JG, Westra WH, Boghaert ER, Ain KB, Saji M, Zeiger MA, Zimmer SG, Baylin SB. 1998. Distinct patterns of E-cadherin $\mathrm{CpG}$ island methylation in papillary, follicular, Hurthle's cell, and poorly differentiated human thyroid carcinoma. Cancer Res 58:2063-2066.

Grooteclaes ML, Frisch SM. 2000. Evidence for a function of CtBP in epithelial gene regulation and anoikis. Oncogene 19:38233828 .

Guilford P, Hopkins J, Harraway J, McLeod M, McLeod N, Harawira P, Taite H, Scoular R, Miller A, Reeve AE. 1998. E-cadherin germline mutations in familial gastric cancer. Nature 392:402-405.

Guilford PJ, Hopkins JB, Grady WM, Markowitz SD, Willis J, Lynch H, Rajput A, Wiesner GL, Lindor NM, Burgart LJ, Toro TT, Lee D, Limacher JM, Shaw DW, Findlay MP, Reeve AE. 1999. E-cadherin germline mutations define an inherited cancer syndrome dominated by diffuse gastric cancer. Hum Mutat 14: 249-255.

Hajra KM, Ji X, Fearon ER. 1999. Extinction of E-cadherin expression in breast cancer via a dominant repression pathway acting on proximal promoter elements. Oncogene 18:7274-7279.

Hajra KM, Chen DYS, Fearon ER. 2002. The SLUG zinc-finger protein represses E-cadherin in breast cancer. Cancer Res, in press.

Hamaguchi M, Matsuyoshi N, Ohnishi Y, Gotoh B, Takeichi M, Nagai Y. 1993. p60v-src causes tyrosine phosphorylation and inactivation of the N-cadherin-catenin cell adhesion system. EMBO J 12:307-314.

Hazan RB, Norton L. 1998. The epidermal growth factor receptor modulates the interaction of E-cadherin with the actin cytoskeleton. J Biol Chem 273:9078-9084.

Hazan RB, Kang L, Whooley BP, Borgen PI. 1997. N-cadherin promotes adhesion between invasive breast cancer cells and the stroma. Cell Adhes Commun 4:399-411.

Hazan RB, Phillips GR, Qiao RF, Norton L, Aaronson SA. 2000. Exogenous expression of $\mathrm{N}$-cadherin in breast cancer cells induces cell migration, invasion, and metastasis. J Cell Biol 148: 779-790.

He TC, Sparks AB, Rago C, Hermeking H, Zawel L, da Costa LT, Morin PJ, Vogelstein B, Kinzler KW. 1998. Identification of cMYC as a target of the APC pathway. Science 281:1509-1512.

He TC, Chan TA, Vogelstein B, Kinzler KW. 1999. PPARס is an APC-regulated target of nonsteroidal anti-inflammatory drugs. Cell 99:335-345.

Henderson BR. 2000. Nuclear-cytoplasmic shuttling of APC regulates $\beta$-catenin subcellular localization and turnover. Nat Cell Biol 2:653-660.

Hennig G, Behrens J, Truss M, Frisch S, Reichmann E, Birchmeier W. 1995. Progression of carcinoma cells is associated with alterations in chromatin structure and factor binding at the E-cadherin promoter in vivo. Oncogene 11:475-484.

Hirohashi S. 1998. Inactivation of the E-cadherin-mediated cell adhesion system in human cancers. Am J Pathol 153:333-339.

Hordijk PL, ten Klooster JP, van der Kammen RA, Michiels F, Oomen LC, Collard JG. 1997. Inhibition of invasion of epithelial cells by Tiam1-Rac signaling. Science 278:1464-1466.

Hoschuetzky H, Aberle H, Kemler R. 1994. $\beta$-Catenin mediates the interaction of the cadherin-catenin complex with epidermal growth factor receptor. J Cell Biol 127:1375-1380.

Hovanes K, Li TW, Munguia JE, Truong T, Milovanovic T, Lawrence Marsh J, Holcombe RF, Waterman ML. 2001. $\beta$-Cateninsensitive isoforms of lymphoid enhancer factor-1 are selectively expressed in colon cancer. Nat Genet 28:53-57.

Hulsken J, Birchmeier W, Behrens J. 1994. E-cadherin and APC compete for the interaction with $\beta$-catenin and the cytoskeleton. J Cell Biol 127:2061-2069.
Islam S, Carey TE, Wolf GT, Wheelock MJ, Johnson KR. 1996. Expression of N-cadherin by human squamous carcinoma cells induces a scattered fibroblastic phenotype with disrupted cellcell adhesion. J Cell Biol 135:1643-1654.

Ji X, Woodard AS, Rimm DL, Fearon ER. 1997. Transcriptional defects underlie loss of E-cadherin expression in breast cancer. Cell Growth Differ 8:773-778.

Jiang WG. 1996. E-cadherin and its associated protein catenins, cancer invasion and metastasis. Br J Surg 83:437-446.

Kaibuchi K, Kuroda S, Fukata M, Nakagawa M. 1999. Regulation of cadherin-mediated cell-cell adhesion by the Rho family GTPases. Curr Opin Cell Biol 11:591-596.

Kanai Y, Ochiai A, Shibata T, Oyama T, Ushijima S, Akimoto S, Hirohashi S. 1995. c-erbB-2 gene product directly associates with $\beta$-catenin and plakoglobin. Biochem Biophys Res Commun 208: 1067-1072.

Kanner SB, Reynolds AB, Parsons JT. 1991. Tyrosine phosphorylation of a 120-kilodalton pp60src substrate upon epidermal growth factor and platelet-derived growth factor receptor stimulation and in polyomavirus middle-T-antigen-transformed cells. Mol Cell Biol 11:713-720.

Kawanishi J, Kato J, Sasaki K, Fugii S, Watanabe N, Niitsu Y. 1995. Loss of E-cadherin-dependent cell-cell adhesion due to mutation of the $\beta$-catenin gene in a human cancer cell line, HSC-39. Mol Cell Biol 15:1175-1181.

Keller G, Vogelsang H, Becker I, Hutter J, Ott K, Candidus S, Grundei T, Becker K-F, Mueller J, Siewert JR, Hofler H. 1999. Diffuse type gastric and lobular breast carcinoma in a familial gastric patient with an E-cadherin germline mutation. Am J Pathol 155:337-342

Knudson AG. 1985. Hereditary cancer, oncogenes, and antioncogenes. Cancer Res 45:1437-1443.

Kodama S, Ikeda S, Asahara T, Kishida M, Kikuchi A. 1999. Axin directly interacts with plakoglobin and regulates its stability. J Biol Chem 274:27682-27688.

Koh TJ, Bulitta CJ, Fleming JV, Dockray GJ, Varro A, Wang TC. 2000. Gastrin is a target of the $\beta$-catenin/TCF-4 growth-signaling pathway in a model of intestinal polyposis. J Clin Invest 106:533539.

Kolligs FT, Hu G, Dang CV, Fearon ER. 1999. Neoplastic transformation of RK3E by mutant $\beta$-catenin requires deregulation of Tcf/Lef transcription but not activation of c-myc expression. Mol Cell Biol 19:5696-5706.

Kolligs FT, Kolligs B, Hajra KM, Hu G, Tani M, Cho KR, Fearon ER. 2000. $\gamma$-Catenin is regulated by the APC tumor suppressor and its oncogenic activity is distinct from that of $\beta$-catenin. Genes Dev 14:1319-1331.

Kremmidiotis G, Baker E, Crawford J, Eyre HJ, Nahmias J, Callen DF. 1998. Localization of human cadherin genes to chromosome regions exhibiting cancer-related loss of heterozygosity. Genomics 49:467-471.

Kuroda S, Fukata M, Nakagawa M, Fujii K, Nakamura T, Ookubo T, Izawa I, Nagase T, Nomura N, Tani H, Shoji I, Matsuura Y, Yonehara S, Kaibuchi K. 1998. Role of IQGAP1, a target of the small GTPases Cdc42 and Rac1, in regulation of E-cadherinmediated cell-cell adhesion. Science 281:832-835.

Kypta RM, Su H, Reichardt LF. 1996. Association between a transmembrane protein tyrosine phosphatase and the cadherin-catenin complex. J Cell Biol 134:1519-1529.

Laurent-Puig P, Beroud C, Soussi T. 1998. APC gene: database of germline and somatic mutations in human tumors and cell lines. Nucleic Acids Res 26:269-270.

Lee SW. 1996. H-cadherin, a novel cadherin with growth inhibitory functions and diminished expression in human breast cancer. Nat Med 2:776-782.

Li C, Bapat B, Alman BA. 1998. Adenomatous polyposis coli gene mutation alters proliferation through its $\beta$-catenin-regulatory function in aggressive fibromatosis (desmoid tumor). Am J Pathol 153:709-714

Liu W, Dong X, Mai M, Seelan RS, Taniguchi K, Krishnadath KK, Halling KC, Cunningham JM, Oian C, Christensen E, Roche PC, Smith DI, Thibodeau SN. 2000. Mutations in AXIN2 cause colorectal cancer with defective mismatch repair by activating $\beta$-catenin/TCF signalling. Nat Genet 26:146-147.

MacDougall JR, Matrisian LM. 1995. Contributions of tumor and stromal matrix metalloproteinases to tumor progression, invasion and metastasis. Cancer Metastasis Rev 14:351-362.

Matsuyoshi N, Hamaguchi M, Taniguchi S, Nagafuchi A, Tsukita S, Takeichi M. 1992. Cadherin-mediated cell-cell adhesion is per- 
turbed by $\mathrm{v}$-src tyrosine phosphorylation in metastatic fibroblasts. J Cell Biol 118:703-714.

Morin PJ. 1999. $\beta$-Catenin signaling and cancer. Bioessays 21:10211030.

Morton RA, Ewing CM, Nagafuchi A, Tsukita S, Isaacs WB. 1993. Reduction of E-cadherin levels and deletion of the $\alpha$-catenin gene in human prostate cancer cells. Cancer Res 53:3585-3590.

Muta H, Noguchi M, Kanai Y, Ochiai A, Nawata H, Hirohashi S. 1996. E-cadherin gene mutations in signet ring cell carcinoma of the stomach. Jpn J Cancer Res 87:843-848.

Nagar B, Overduin M, Ikura M, Rini JM. 1996. Structural basis of calcium-induced E-cadherin rigidification and dimerization. $\mathrm{Na}$ ture 380:360-364.

Nakanishi Y, Ochiai A, Akimoto S, Kato H, Watanabe H, Tachimori Y, Yamamoto S, Hirohashi S. 1997. Expression of E-cadherin, $\alpha$-catenin, $\beta$-catenin and plakoglobin in esophageal carcinomas and its prognostic significance. Oncology 54:158-165.

Nieman MT, Prudoff RS, Johnson KR, Wheelock MJ. 1999. Ncadherin promotes motility in human breast cancer cells regardless of their E-cadherin expression. J Cell Biol 147:631-644.

Nusse R. 2001. Making head or tail of Dickkopf. Nature 411:255256.

Ochiai A, Akimoto S, Kanai Y, Shibata T, Oyama T, Hirohashi S. 1994. c-erbB-2 gene product associates with catenins in human cancer cells. Biochem Biophys Res Commun 205:73-78.

Oda T, Kanai Y, Shimoyama Y, Nagafuchi A, Tsukita S, Hirohashi S. 1993. Cloning of the human $\alpha$-catenin cDNA and its aberrant mRNA in a human cancer cell line. Biochem Biophys Res Commun 193:897-904.

Oyama T, Kanai Y, Ochiai A, Akimoto S, Oda T, Yanagihara K, Nagafuchi A, Tsukita S, Shibamoto S, Ito F. 1994. A truncated $\beta$-catenin disrupts the interaction between E-cadherin and $\alpha$-catenin: a cause of loss of intercellular adhesiveness in human cancer cell lines. Cancer Res 54:6282-6287.

Papadavid E, Katsambas A. 2001. The interactions and role of epithelial cadherin and catenins in tumorigenicity. Int J Dermatol 40:254-257.

Pawson T, Nash P. 2000. Protein-protein interactions define specificity in signal transduction. Genes Dev 14:1027-1047.

Peifer M, Polakis P. 2000. Wnt signaling in oncogenesis and embryogenesis: a look outside the nucleus. Science 287:1606-1609.

Perez-Moreno MA, Locascio A, Rodrigo I, Dhondt G, Portillo F, Nieto MA, Cano A. 2001. A new role for E12/E47 in the repression of E-cadherin expression and epithelial-mesenchymal transitions. J Biol Chem 276:27424-27431.

Pishvaian MJ, Feltes CM, Thompson P, Bussemakers MJ, Schalken JA, Byers SW. 1999. Cadherin-11 is expressed in invasive breast cancer cell lines. Cancer Res 59:947-952.

Polakis P. 1995. Mutations in the APC gene and their implications for protein structure and function. Curr Opin Genet Dev 5:66-71.

Polakis P. 2000. Wnt signaling and cancer. Genes Dev 14:18371851.

Polakis P. 2001. More than one way to skin a catenin. Cell 105:563566.

Poser I, Dominguez D, de Herreros AG, Varnai A, Buettner R, Bosserhoff AK. 2001. Loss of E-cadherin expression in melanoma cells involves up-regulation of the transcriptional repressor Snail. J Biol Chem 276:24661-24666.

Reynolds AB, Roesel DJ, Kanner SB, Parsons JT. 1989. Transformation-specific tyrosine phosphorylation of a novel cellular protein in chicken cells expressing oncogenic variants of the avian cellular src gene. Mol Cell Biol 9:629-638.

Richards FM, McKee SA, Rajpar MH, Cole TR, Evans DG, Jankowski JA, McKeown C, Sanders DS, Maher ER. 1999. Germline E-cadherin gene (CDH1) mutations predispose to familial gastric cancer and colorectal cancer. Hum Mol Genet 8:607-610.

Risinger JI, Berchuck A, Kohler MF, Boyd J. 1994. Mutations of the E-cadherin gene in human gynecologic cancers. Nat Genet 7:98102.

Roe S, Koslov ER, Rimm DL. 1998. A mutation in $\alpha$-catenin disrupts adhesion in clone A cells without perturbing its actin and $\beta$-catenin binding activity. Cell Adhes Commun 5:283-296.

Roose J, Huls G, van Beest M, Moerer P, van der Horn K, Goldschmeding R, Logtenberg T, Clevers H. 1999. Synergy between tumor suppressor APC and the $\beta$-catenin-Tcf4 target Tcf1. Science 285:1923-1926.

Rosin-Arbesfeld R, Townsley F, Bienz M. 2000. The APC tumour suppressor has a nuclear export function. Nature 406:1009-1012.

Rubinfeld B, Souza B, Albert I, Munemitsu S, Polakis P. 1995. The APC protein and E-cadherin form similar but independent com- plexes with $\alpha$-catenin, $\beta$-catenin, and plakoglobin. J Biol Chem 270:5549-5555.

Satoh S, Daigo Y, Furukawa Y, Kato T, Miwa N, Nishiwaki T, Kawasoe T, Ishiguro H, Fujita M, Tokino T, Sasaki Y, Imaoka S, Murata M, Shimano T, Yamaoka Y, Nakamura Y. 2000. AXIN1 mutations in hepatocellular carcinomas, and growth suppression in cancer cells by virus-mediated transfer of AXIN1. Nat Genet $24: 245-250$

Shibamoto S, Hayakawa M, Takeuchi K, Hori T, Oku N, Miyazawa K, Kitamura N, Takeichi M, Ito F. 1994. Tyrosine phosphorylation of $\beta$-catenin and plakoglobin enhanced by hepatocyte growth factor and epidermal growth factor in human carcinoma cells. Cell Adhes Commun 1:295-305.

Shibata T, Gotoh M, Ochiai A, Hirohashi S. 1994. Association of plakoglobin with APC, a tumor suppressor gene product, and its regulation by tyrosine phosphorylation. Biochem Biophys Res Commun 203:519-522.

Shibata T, Ochiai A, Gotoh M, Machinami R, Hirohashi S. 1996a. Simultaneous expression of cadherin-11 in signet-ring cell carcinoma and stromal cells of diffuse-type gastric cancer. Cancer Lett 99:147-153.

Shibata T, Ochiai A, Kanai Y, Akimoto S, Gotoh M, Yasui N, Machinami R, Hirohashi S. 1996b. Dominant negative inhibition of the association between $\beta$-catenin and c-erbB- 2 by $\mathrm{N}$-terminally deleted $\beta$-catenin suppresses the invasion and metastasis of cancer cells. Oncogene 13:883-889.

Shimoyama Y, Nagafuchi A, Fujita S, Gotoh M, Takeichi M, Tsukita S, Hirohashi S. 1992. Cadherin dysfunction in a human cancer cell line: possible involvement of loss of $\alpha$-catenin expression in reduced cell-cell adhesiveness. Cancer Res 52:5770-5774.

Shiozaki H, Kadowaki T, Doki Y, Inoue M, Tamura S, Oka H, Iwazawa T, Matsui S, Shimaya K, Takeichi M, Mori T. 1995. Effect of epidermal growth factor on cadherin-mediated adhesion in a human oesophageal cancer cell line. Br J Cancer $71: 250-258$

Shtutman M, Zhurinsky J, Simcha I, Albanese C, D'Amico M, Pestell R, Ben-Ze'ev A. 1999. The cyclin D1 gene is a target of the $\beta$-catenin/LEF-1 pathway. Proc Natl Acad Sci USA 96:55225527.

Simcha I, Geiger B, Yehuda-Levenberg S, Salomon D, Ben-Ze'ev A. 1996. Suppression of tumorigenicity by plakoglobin: an augmenting effect of N-cadherin. J Cell Biol 133:199-209.

Takaishi K, Sasaki T, Kotani H, Nishioka H, Takai Y. 1997. Regulation of cell-cell adhesion by rac and rho small $G$ proteins in MDCK cells. J Cell Biol 139:1047-1059.

Takeda H, Nagafuchi A, Yonemura S, Tsukita S, Behrens J, Birchmeier W, Tsukita S. 1995. V-src kinase shifts the cadherin-based cell adhesion from the strong to the weak state and beta catenin is not required for the shift. J Cell Biol 131:1839-1847.

Takeichi M. 1991. Cadherin cell adhesion receptors as a morphogenic regulator. Science 251:1451-1455.

Tamura G, Yin J, Wang S, Fleisher AS, Zou T, Abraham JM, Kong D, Smolinski KN, Wilson KT, James SP, Silverberg SG, Nishizuka S, Terashima M, Motoyama T, Meltzer SJ. 2000. E-cadherin gene promoter hypermethylation in primary human gastric carcinomas. J Natl Cancer Inst 92:569-573.

Tetsu O, McCormick F. 1999. $\beta$-Catenin regulates expression of cyclin D1 in colon carcinoma cells. Nature 398:422-426.

Tomita K, van Bokhoven A, van Leenders GJ, Ruijter ET, Jansen CF, Bussemakers MJ, Schalken JA. 2000. Cadherin switching in human prostate cancer progression. Cancer Res 60:3650-3654.

van de Wetering M, Barker N, Harkes IC, van der Heyden M, Dijk NJ, Hollestelle A, Klijn JG, Clevers H, Schutte M. 2001. Mutant E-cadherin breast cancer cells do not display constitutive Wnt signaling. Cancer Res 61:278-284.

Vermeulen SJ, Nollet F, Teugels E, Vennekens KM, Malfait F, Philippe J, Speleman F, Bracke ME, van Roy FM, Mareel MM. 1999. The $\alpha$ E-catenin gene (CTNNA1) acts as an invasion-suppressor gene in human colon cancer cells. Oncogene 18:905-915.

Vleminckx K, Vakaet L, Mareel M, Fiers W, Van Roy F. 1991. Genetic manipulation of E-cadherin expression by epithelial tumor cells reveals an invasion suppressor role. Cell 66:107-119.

Watabe M, Nagafuchi A, Tsukia S, Takeichi M. 1994. Induction of polarized cell-cell association and retardation of growth by activation of the E-cadherin-catenin adhesion system in a dispersed carcinoma line. J Cell Biol 127:247-256.

Wilson CL, Matrisian LM. 1996. Matrilysin: an epithelial matrix metalloproteinase with potentially novel functions. Int J Biochem Cell Biol 28:123-136.

Wilson CL, Heppner KJ, Labosky PA, Hogan BL, Matrisian LM. 
1997. Intestinal tumorigenesis is suppressed in mice lacking the metalloproteinase matrilysin. Proc Natl Acad Sci USA 94:1402-1407.

Wu R, Zhai Y, Fearon ER, Cho KR. 2001. Diverse mechanisms of $\beta$-catenin deregulation in ovarian endometrioid adenocarcinomas. Cancer Res 61:8247-8255.

Yokoyama K, Kamata N, Hayashi E, Hoteiya T, Ueda N, Fujimoto R, Nagayama M. 2001. Reverse correlation of E-cadherin and snail expression in oral squamous cell carcinoma cells in vitro. Oral Oncol 37:65-71.

Yoshiura K, Kanai Y, Ochiai A, Shimoyama Y, Sugimura T, Hiro- hashi S. 1995. Silencing of the E-cadherin invasion-suppressor gene by $\mathrm{CpG}$ methylation in human cancers. Proc Natl Acad Sci USA 92:7416-7419.

Zhurinsky J, Shtutman M, Ben-Ze'ev A. 2000. Plakoglobin and $\beta$-catenin: protein interactions, regulation and biological roles. J Cell Sci 113:3127-3139.

Zondag GC, Evers EE, ten Klooster JP, Janssen L, van der Kammen RA, Collard JG. 2000. Oncogenic Ras downregulates Rac activity, which leads to increased Rho activity and epithelial-mesenchymal transition. J Cell Biol 149:775-782. 